\title{
A Case Study in Collaboration: Assessing Academic Librarian/ Faculty Partnerships
}

\section{Deborah B. Gaspar and Karen A. Wetzel}

\begin{abstract}
Undergraduates attending The George Washington University are required to take courses in the University Writing Program. When it was introduced in 2004, this innovative program institutionalized collaboration between librarians and writing professors. The program was designed to support the university's strategic goal to enhance challenge, discovery, and quality in student education. Beginning in 2005, instruction librarians crafted a survey to elicit anonymous feedback from their faculty partners to measure the impact of the library partnership on student learning. The survey is administered annually to explore faculty perceptions and monitor trends. Responses to the survey identify significant strengths resulting from this collaboration as well as specific topics needing further attention.
\end{abstract}

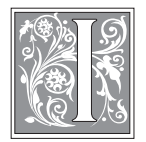

n June 2003, The George Washington University published a strategic plan, Sustaining Momentum, Maximizing Growth. It established direction for the university and created new programs deemed critical to academic excellence. One key initiative was the University Writing Program (UWP). This innovation was designed to build writing and research competencies in freshmen and foster continued growth in those areas throughout their undergraduate careers. The UWP broke new ground as it institutionalized collaboration between librarians and writing professors, "to enhance challenge, discovery, and quality in undergraduate education." ${ }^{1}$ The UWP continues as a universitywide literacy requirement that includes the First-Year
Writing Program (UW20), the Writing in the Disciplines (WID) Program for sophomores and juniors, and the University Writing Center.

In the fall of 2004, the university began gradual implementation of the UWP. One-third of incoming freshmen were assigned to a UW20 class: an intensive, thematically based writing course featuring a writing professor and a class librarian. Enrollment is capped at 15 students to ensure that the professor has sufficient time for close attention to each student's progress. The readings and writings for each of these courses are focused on an instructor-chosen topic selected to generate debate, writing, research, and interest. For example, in recent semesters students wrote about issues of class mobility, regionalism in the United States, and

Deborah B. Gaspar is Reference and Instruction Librarian in the Gelman Library at The George Washington University; e-mail: dgaspar@gwu.edu. Karen A. Wetzel is Standards Program Manager at the National Information Standards Organization in Baltimore, Maryland; e-mail: kwetzel@niso.org. 
global warming. Typically, the librarian and writing professor collaborate to meet curricular requirements, plan instruction sessions in the library (two or three per class per semester), and design research assignments. Contact information for both is included on the course syllabus and on the course's Blackboard site. Likewise, the course evaluation developed by the University Office of Academic Planning and Assessment queries students about their library research experience in addition to their classroom experience.

Librarians working with the UWP are members of the Education and Instruction Group (EIG) at Gelman Library. During the second year of program implementation, a task force of EIG members initiated various evaluation methods, both internal to EIG and externally to other UWP stakeholders. One of their first activities was to design a faculty survey to measure the effectiveness of the librarian/faculty partnership as perceived by the writing professors. Drawing on the framework of Ada Ducas and Nicole Michaud-Oystry in their study at the University of Manitoba, ${ }^{2}$ task force members asked questions designed to investigate the current state of the collaboration and explore how to grow those collaborative relationships. The EIG task force asserted the survey would serve as a starting point for discussion between librarians and faculty about the parts of collaboration that worked well. A report by Annmarie Singh on the survey of faculty at Hofstra University $^{3}$ regarding their perceptions of students' information literacy learning was also informative, as the task force was interested to learn if faculty members felt that librarian-led instruction improved student learning.

The UWP, as is frequently the case with new programs, had been subject to close scrutiny and frequent evaluation. Therefore, the EIG task force tailored a very brief survey containing questions focused solely on the library sessions and their impact as key indicators of the efficacy of librarian-instructor partnerships.
The survey was Web-based, anonymous, and streamlined to avoid survey fatigue. This tool was designed to provide focused insight into how well this aspect of the program was promoting student scholarship and critical thinking.

At the conclusion of each fall semester, EIG members have asked faculty members teaching in the First Year Writing Program (UW20) to provide feedback. Each instructional librarian sends a link inviting their faculty partners to complete the anonymous, Web-based survey. Although there are eight questions on the survey annually, five remain consistent from year to year to monitor trends. The remaining three questions on the survey change each year to query specific issues identified during the semester. Forty-five percent $(45 \%)$ of faculty members completed the survey in 2005. In 2006, there was a slight increase in faculty responses: 55 percent completed the survey. This response was seen as an indication that faculty respondents understood that survey results informed librarian practice and engendered collaborative discussion. Response to the 2007 survey, however, dropped back to 51 percent.

(The 2004 survey follows in Addendum 1.)

\section{Literature Review}

Dick Raspa and Dane Ward outline the tenents of successful collaboration with emphasis on communication, persistence, and a shared project. ${ }^{4}$ They provide case studies of programs exemplifying their definition. Trudi E. Jacobson and Thomas P. Mackey edited a monograph documenting collaborative initiatives in academic libraries. ${ }^{5}$ Further articles chronicling successful faculty and librarian collaboration abound (Callison, Budny and Thomes; ${ }^{6}$ Fiegen, Cherry and Watson; ${ }^{7}$ Lampert; $^{8}$ Sanborn ${ }^{9}$ ). As these partnerships have become more standard, practitioners and researchers alike have studied various aspects of the practice. Kate Manual, Susan Beck, and Molly Molloy conducted interviews 


\begin{tabular}{|l|c|c|c|c|c|c|c|}
\hline \multicolumn{7}{|c|}{ TABLE 1 } \\
\hline \hline & Sections & $\begin{array}{c}\text { Students } \\
\text { per } \\
\text { Section }\end{array}$ & $\begin{array}{c}\text { Faculty } \\
\text { Members }\end{array}$ & $\begin{array}{c}\text { EIG } \\
\text { Librarians }\end{array}$ & $\begin{array}{c}\text { EIG } \\
\text { Classes } \\
\text { Taught }\end{array}$ & $\begin{array}{c}\text { EIG } \\
\text { Classes } \\
\text { per } \\
\text { Section }\end{array}$ & $\begin{array}{c}\text { Individual } \\
\text { Student } \\
\text { Librarian } \\
\text { Meetings }\end{array}$ \\
\hline Fall 2005 & 81 & 15 & 52 & 12 & 199 & 2.46 & 173 \\
\hline Fall 2006 & 86 & 15 & 42 & 12 & 219 & 2.55 & 226 \\
\hline Fall 2007 & 87 & 15 & 49 & 12 & 214 & 2.45 & 219 \\
\hline Note that the above represent fall semesters only. & & & & \\
\hline
\end{tabular}

with 21 faculty who regularly work with instruction librarians. Their methodology elicits responses in the subjects' own words on a range of faculty attitudes toward student research and the role of librarians in education. Of interest is their finding that "Faculty value strong library and information research skills because when students have these they can find information quickly for whatever needs they have." ${ }^{10}$ Lisa Given and Heidi Julien employ discourse analysis methodology on librarian discussions related to collaboration on BI-L/ILI-L. They examine librarian attitudes to faculty relationships and librarian beliefs about faculty perceptions. Their findings document librarian frustration with faculty assignments, scheduling, and participation. ${ }^{11}$ The study documented in this article builds on the existing literature but extends it: this is a longitudinal study examining collaborative practice in a growing program.

\section{Partnership Implementation}

One-third of incoming freshmen enrolled in UW20 in the fall of 2004. During the fall 2005 semester, two-thirds of incoming freshmen enrolled in the UWP, resulting in a total of 81 UW20 sections supported by twelve librarians working with 52 instructors.

Full program implementation occurred with the fall 2006 semester, when all freshmen enrolled in the program. Although the number of EIG librarians working with the University Writing Program remained the same, the number of UW20 faculty dropped to 42 , while the number of sections grew to 86. In 2007 and subsequent years, the program has stabilized with 12 librarians, 49 UW20 faculty, and 87 sections of the course. UW20 students often met with a librarian individually following a class session, and these numbers are captured in the table above. It is important to note that these numbers represent only the fall semester for each year reported on in this article; however, UW20 courses are offered in both fall and spring. Hence, the numbers here represent only 50 percent of the annual totals.

\section{Results}

The following section presents the survey results. Questions 1 through 5 below appeared on each of the three annual surveys; following each is a comparison of the results as received each year. Questions 6 through 8 appeared on the original 2005 survey but were altered as the task force modified the survey to reflect findings or contextual issues. The discussion portion following these questions will explain the rationale for the change and introduce the replacement question.

1. What were your learning goals of the Library Instruction session(s)?

When the university's strategic plan was developed, a Writing Program Task Force charged with designing the UWP identified principal information literacy objectives to clarify the library's role in the program. These objectives were distributed to incoming faculty and new EIG librarians, and are the foundation for the curriculum (Addendum 2). To measure whether these objectives were 
in fact consistent with faculty expectations for the library research component, the 2005 survey first asked respondents to articulate their own learning goals for the sessions conducted by their partner librarian. The faculty responses each year have been systematically coded for recurring themes embedded in the respondents' own words. ${ }^{12}$ When responses to the first survey were received, six key themes emerged. Listed in order of the most frequently occurring theme to the least, the concepts specified by the faculty stated that students should:

1. Learn how to use different databases and the library catalog: 15 (79\%) responses.

2. Learn specific search strategies that contribute to more efficient searching: 9 (47\%) responses.

3. Evaluate sources and critically select appropriate databases and formats: 8 $(42 \%)$ responses.

4. Be able to differentiate between sources to select appropriate content for the results students need: 8 (42\%) responses. Examples of different content types listed included pop culture, personal narratives, and scholarly articles.

5. Understand that there is a recursive relationship between writing and research: 7 (39\%) responses.

6. Be able to refine topics and create search statements to reflect those topics: $3(16 \%)$ responses.

The faculty comments were especially informative for the instructional librarians. Of the six topics listed, five were specified in the Writing Program Task Force's objectives for UW20 classes:

1. Translate a topic to a search statement.

2. Develop search terms.

3. Utilize database tools (such as boolean operators and truncation).

4. Search for books using the catalog.

5. Effectively search for articles using online databases.

The fifth theme listed above-the recursive relationship between writing and research - is a theoretical perspective not specified in the formal curriculum. However, it informs the pedagogy of the EIG librarians. As one respondent wrote, library instruction is " $\mathrm{t}$ ]raining students to research for argument, not just information." Another response went further, explaining how she or he hoped that the library sessions would "help students not only to find appropriate sources for their projects, but to think critically about disciplinary assumptions and about how to apply others' work to their own interests."

The emergence of this key principle from survey responses and its absence in the library goals underscored that the tie between writing and research needed to be more clearly stated by the program generally and by the library particularly. It also indicated a need to confirm whether current library instruction, as exemplified by the other five goals, should include concepts and aspects that would highlight and expound upon this recursive relationship. Another question that came up as a result of this initial survey was whether the librarians assumed that the recursive connection was being taught by the writing instructors and therefore was unnecessary or inappropriate for the librarian partners to include. The faculty response, however, pointed to a need to further examine how both the librarians and faculty should coordinate and complement each others' teaching to elucidate this key foundation.

Subsequent surveys have included this question about learning goals as well. Responses have differed little from year to year, though the emphasis has shifted slightly. For example, the 2007 iteration of the survey found that more respondents focused on student reliance on electronic resources to the detriment of valuable print sources. As one respondent noted, "[K]nowledge of the library and [its] resources are important learning goals because they increase the breadth of sources for student papers" and introduce "resources beyond Google." Another respondent put this concern more succinctly: "Sadly, print is dead as far as my 


\begin{tabular}{|c|c|c|c|c|c|c|}
\hline \multicolumn{7}{|c|}{$\begin{array}{l}\text { TABLE } 2 \\
2005 \text { How Effectively Did the Library Sessions: } \\
\text { Please rank the following on a scale of } 1 \text { (poor) to } 5 \text { (excellent). }\end{array}$} \\
\hline & 1 & 2 & 3 & 4 & 5 & Avg. \\
\hline $\begin{array}{l}\text { Meet the information needs of } \\
\text { your students }\end{array}$ & & 1 & 1 & 3 & 14 & 3.68 \\
\hline Meet your expectations & & 2 & 1 & 1 & 15 & 3.95 \\
\hline Support course & & 2 & 1 & 4 & 12 & 3.16 \\
\hline
\end{tabular}

students are concerned." Despite these concerns, however, faculty goals for the library sessions have remained essentially consistent.

\section{How effective were the library ses- sions?}

Faculty members were asked if the sessions were effective in three areas: from the students', instructors', and content perspectives. The responses from 2005 are detailed below:

Optional comments for this question documented mixed feedback about faculty perspectives and how they felt their students responded to library instruction. For instance, one comment stated that the library sessions were: "More than I could have hoped for!" However, another was less enthusiastic: "The first session met all of my needs. The second session was less successful." One instructor added, "Most [students] found the sessions very helpful; some thought they already knew everything, but in fact did not." Most surprising about the results of this question is that, though librarians were deemed fairly effective in meeting faculty expectations, they were rated less effective at supporting course content. This seemingly contradictory response pointed again to an area for additional discussion and clarification between the UW20 partners.

When EIG librarians reviewed these first survey findings, various members expressed how, at that stage of the program, they were grappling with how to balance the need to cover the curriculum while integrating skills into very distinct course sections. Each UW20 section met-and continues to meet-programmatic objectives differently. Faculty assignments also vary, though they all meet the criteria listed in the course template. At the outset, librarians adhered rigorously to the program curriculum. Practices have evolved as librarians have learned to address the curriculum within a more flexible framework. For example, since course topics serve as the vehicle for student writing and research assignments, each course draws on necessarily different sources. Though the curriculum includes location of scholarly sources as a learning goal, some topics rely heavily on contemporary and popular sources, whereas others may require more standard research sources. As a result, the partner librarian must alter instruction practices and schedule library sessions to meet the needs of individual courses. As shown below, the score for "supporting course content" improved with successive surveys as librarians learned to successfully adapt practical applications of curricular mandates to specific topics and assignments.

3. Did the research sessions enhance the course?

The need for improved communication regarding library sessions was empha-

\begin{tabular}{|c|c|c|}
\hline \multicolumn{3}{|c|}{$\begin{array}{c}\text { TABLE 3 } \\
\text { Summary 2006-2007, How } \\
\text { Effectively Did the Library Sessions: }\end{array}$} \\
\hline & Avg. '06 & Avg. '07 \\
\hline $\begin{array}{l}\text { Meet the information } \\
\text { needs of students }\end{array}$ & 4.4 & 4.72 \\
\hline Meet your expectations & 4.16 & 4.48 \\
\hline Support course content & 4.4 & 4.68 \\
\hline
\end{tabular}




\begin{tabular}{|c|c|c|c|c|c|c|}
\hline \multicolumn{7}{|c|}{$\begin{array}{c}\text { TABLE } 4 \\
\text { 2005, Did the Research Sessions Enhance the Course? } \\
\text { Please rank the following on a scale of } 1 \text { (poor) to } 5 \text { (excellent). }\end{array}$} \\
\hline & 1 & 2 & 3 & 4 & 5 & Avg. \\
\hline Tailored instruction to course assignments & & & 1 & 3 & 15 & 5 \\
\hline $\begin{array}{l}\text { Library sessions were scheduled at } \\
\text { appropriate junctures }\end{array}$ & & & 2 & 2 & 15 & 4.94 \\
\hline
\end{tabular}

sized by further conflicting feedback. To determine if the sessions essentially enhanced the course, faculty was asked to rate two factors on a scale of one (lowest) to five (highest). As indicated in table 4, the faculty rated sessions as well timed and tailored to the course. This very positive feedback in year one of the survey did not quite correlate with the lower ranking from the response that same year when asked if library instruction supported course content in question 2, above. Although the difference is not great, it did point to an area where better understanding of expectations could benefit the partnership. In addition, results highlighted the need for closer collaboration early in the development of the course syllabus to tie in the library portion of these courses more closely with the topics and assignments created by the teacher. Responses to this question in subsequent years have remained consistently positive.

4. Did students ask research-related questions following the library sessions? What kinds of questions did they ask?

To gauge student attentiveness during library instruction sessions, the survey asked if students had additional researchrelated questions following the library instruction sessions. Faculty overwhelming responded positively (95\%). When

\section{TABLE 5}

\section{Summary 2006-2007, Did the Research} Sessions Enhance the Course?

\begin{tabular}{|l|c|c|}
\hline \hline & Avg. '06 & Avg. '07 \\
\hline $\begin{array}{l}\text { Tailored instruction to course } \\
\text { assignments: }\end{array}$ & 4.91 & 4.73 \\
\hline $\begin{array}{l}\text { Library sessions were } \\
\text { scheduled at appropriate times: }\end{array}$ & 4.56 & 4.76 \\
\hline
\end{tabular}

elaborating on their response, the majority of respondents indicated that students had follow-up questions on how to locate specific materials (for instance, "How to better use [article databases]" and "Where to find special-topics encyclopedias"). Furthermore, many responses indicated the initial introduction to library resources and services elicited follow-up questions about additional databases, materials available beyond the university, availability of librarian assistance, how to refine searches, and how to use additional library resources. Responses to this question in following years indicate continued student engagement as students articulated questions on evaluation of resources and identifying different types of materials (for instance, scholarly versus popular articles). In addition, results indicate that students frequently asked how to integrate research into particular writing topics (for example, "Many questions related to the resources available in connection to their specific projects" and "During the research project, they asked questions specific to their projectswhere the best places to search would be, more specifically").

The fact that students continue to ask research-specific questions following librarian instruction indicates a likely correlation between the instruction and a greater awareness of research techniques, resources, and librarian assistance. Librarians meet with students frequently during a semester for individual research appointments following the formal class instruction sessions. Although some of these appointments 
TABLE 6

2005 How Would You Rate the Average Quality of Student Research? Please rank the following on a scale of 1 (poor) to 5 (excellent)

\begin{tabular}{|l|l|l|l|l|l|c|}
\hline \hline & $\mathbf{1}$ & $\mathbf{2}$ & $\mathbf{3}$ & $\mathbf{4}$ & $\mathbf{5}$ & Avg. \\
\hline Selected appropriate materials: & & 1 & 2 & 9 & 7 & $\mathbf{4 . 1 6}$ \\
\hline Utilized both print and electronic materials: & & 2 & 3 & 7 & 7 & $\mathbf{4 . 0 0}$ \\
\hline Thoroughness of research in papers: & & 1 & 6 & 7 & 5 & $\mathbf{3 . 8 4}$ \\
\hline
\end{tabular}

are required by faculty, the majority are solicited by students, further showing an interest in library assistance and resources, as well as an understanding of the value of research for their writing. It is encouraging that students ask for follow-up information. This may indicate an understanding by students that information literacy skills learned in UW20 are transferable across courses and disciplines.

5. How would you rate the average quality of student research conducted for this class?

When asked to rate the quality of the student research conducted in their classes, many faculty stated that students varied widely in their capabilities (for example, "Some students did very well, while others didn't" and "It varied from pathetic to excellent, so it's difficult to generalize"). Several comments expressed concern regarding students' reliance on electronic and Internet resources (for example, "Still very hard to get students to move beyond electronic resources, even where it would save them time and labor, and improve the depth of research" and "A number of my students continued to rely on Google a ${ }^{*}$ lot. ${ }^{*}$ I still want to work on getting them to turn *first* to the library resources"). See table 6 for results from the initial survey.

One method of modifying poor research behavior is to offer further instruction on the variety of formats available at the library. This solution correlates with the faculty expectations drawn from the first survey question, especially the themes of using different types of sources and the recursive nature of writing and research. Another option is to require the application of varied resources from multiple formats in student writing in measurable ways (such as reflected in grading). Faculty responses to this question have followed a negative trend, as demonstrated in the chart below.

These responses correlate with results published from an assessment conducted internally by the UWP at the end of the 2006 academic year. Faculty members read a sampling of research papers to assess the program's stated goal: "Enable students to acquire the ability to explore, use, and analyze information resources to meet research objectives."

Scores from this assessment indicated that students had learned and utilized academic information literacy skills. An average of 66 percent of their papers demonstrated strong or adequate abilities for each of the outcomes. Only 10 percent, however, demonstrated exceptional abilities in these areas. The recent report to the faculty of these results ${ }^{13}$ may have

\begin{tabular}{|c|c|c|}
\hline \multicolumn{3}{|c|}{$\begin{array}{c}\text { TABLE } 7 \\
\text { Summary 2006-2007, How Would You } \\
\text { Rate the Average Quality of Student } \\
\text { Research? }\end{array}$} \\
\hline & Avg. '06 & Avg. '07 \\
\hline $\begin{array}{l}\text { Selected appropriate } \\
\text { materials: }\end{array}$ & 4.08 & 4.04 \\
\hline $\begin{array}{l}\text { Utilized both print and } \\
\text { electronic materials: }\end{array}$ & 3.95 & 3.79 \\
\hline $\begin{array}{l}\text { Thoroughness of } \\
\text { research in papers: }\end{array}$ & 3.86 & 3.58 \\
\hline
\end{tabular}


impacted 2007 faculty responses to the librarian-generated survey asking about the quality of research in students' papers. It is difficult to determine if the decline in ratings is attributable to increased faculty awareness of the learning objectives or to poorer student work.

\section{Alterations to Survey Questions}

Three of the questions were altered after the first iteration of the survey. The following section examines these changes and offers the rationale for them.

6. Did you discuss library materials with your students beyond the library sessions?

In the initial survey, faculty members were asked if library materials were discussed in class prior to the library session. This question was posed to better understand how research was being introduced in class and to provide a figure for comparison in survey results. All faculty respondents indicated that electronic and print library resources were equally introduced. This demonstrated to students that the research component of the course was not segregated but valued by the writing faculty.

This question was replaced in subsequent surveys because, as noted above, the unanimity and evenness of the responses provided insufficient information. Hence, the question "Did you discuss library materials with your students before the library session?" was rephrased to better highlight the connection between research and writing. It was replaced with
"How did you discuss the relationship between writing and research with your students beyond the library sessions?" This allowed results from the first survey to be further explored. In that survey, 39 percent of respondents specified that the faculty/librarian partnership should promote student understanding of the recursive relationship between writing and research.

When the rephrased question appeared on the 2006 survey, 22 faculty members submitted comments. These responses were systematically coded for recurring themes embedded in the respondents' own words. Three key themes emerged as most discussed by faculty in their classrooms. They are listed below in order of frequency:

1. Critical thinking about the iterative loop between the sources and the thesis: 11 comments (50\%)

2. How suitable sources support and build an argument: 7 comments (32\%)

3. How appropriate sources extend the conversation or discourse: 6 comments $(27 \%)$

Nine respondents $(41 \%)$ noted the extensive time allocated to discussion and learning about the relationship between writing and research, an indication of their belief that this concept is fundamental to the curriculum. As one respondent commented, "We talked about it as a loop... that especially in the early stages of research, when we are writing to learn what we know/think about a topic, the research can shape and change that radi-

\begin{tabular}{|l|c|c|c|c|}
\hline \multicolumn{5}{|c|}{ TABLE 8 } \\
\hline & $\begin{array}{c}\text { Don't } \\
\text { know }\end{array}$ & $\begin{array}{c}\text { Awareness } \\
\text { of }\end{array}$ & Competent & NA \\
\hline \hline & & & $18(100 \%)$ & \\
\hline Using article databases to find articles: & & $1(6 \%)$ & $16(89 \%)$ & $1(6 \%)$ \\
\hline $\begin{array}{l}\text { Able to differentiate between scholarly } \\
\text { and popular sources: }\end{array}$ & & $2(11 \%)$ & $14(78 \%)$ & $2(11 \%)$ \\
\hline $\begin{array}{l}\text { Using reference materials for } \\
\text { background information: }\end{array}$ & & & $18(100 \%)$ & \\
\hline Using the library catalog to locate books: & & & & \\
\hline
\end{tabular}


cally, which in turn changes the direction of the research." Strategies faculty used to discuss this research/writing connection included annotated bibliographies, class discussions, individual discussions, and posting thesis statements to the Blackboard course management system.

7. What level of knowledge should a student demonstrate about the use of the library for research after completing this course?

The faculty were near unanimous on the initial survey regarding what research skills students should learn in UW20. This confirmed that writing instructors and librarians agreed about basic library requirements.

The similarity of responses to faculty objectives for the library sessions stated in response to question one did not inform planning. Hence, this question was replaced on subsequent surveys. Since faculty identified student reliance on electronic resources, either Google or fulltext databases, as an important theme in previous surveys, the 2007 version asked about their strategies to address student reliance on electronic resources. Respondents were provided with a checklist of possible strategies, and most indicated that they used a combination of the following:

- Guidelines in their assignment descriptions: 20 faculty members included specific guidelines in assignments.

- A separate class session for discussion: 19 respondents dedicated class time beyond the librarian-led sessions to discuss sources with their students.

- Examples of a good selection of sources: 15 faculty members provided students with examples of bibliographies that met class criteria.

- Grade points for final bibliographies: 13 respondents indicated that student grades reflected source selection.

\section{Faculty Learning}

The question "Did you learn anything new during the library sessions that will help you with your research and/or teaching?" was deleted after the initial survey. Faculty responses indicating that they always learned something new were unanimous. Although gratifying, this was not informative. Recent surveys ask the following: "How did your librarian partner offer input into the structure of the course and/or assignments?" Responses to the 2005 survey indicated that the faculty/librarian partnerships were working in many ways but did not capture the level of collaboration or cooperation occurring between partners. The new question was designed to serve as a reminder that librarians can and should participate in course preparation, if they were not already doing so. Furthermore, faculty responses might identify opportunities for further collaboration to improve student research practices.

Responses have indicated that many faculty/librarian partnerships work well at a coordination level-selecting dates for library instruction (an activity mentioned by most respondents) with the librarian providing instruction aligned to the faculty-designed syllabus. Some librarian/faculty partnerships, however, have moved into active collaboration, where partners discuss and design assignments and/or the syllabus. Most of the collaboration at this level is built upon existing cooperative frameworks, such as the timing of the library instruction sessions: "[My library partner] helped with integrating the library sessions with the often difficult concept of interpretive frameworks." Six responses indicated that the partner librarian contributed to the design of assignments; for instance, "We wrote the assignment together. I worked out the syllabus after we did this." Others noted that librarian contributions to the course included generating handouts, suggesting sources and readings, designing exercises, and posting to Blackboard. One faculty member said, "We've talked so often about the course and assignment design that I'm not really sure who came up with what."

Collaborative practices reflect the personalities of the partners and shared 
interest in the course topic. Discussions beyond and around survey results have highlighted innovative practices utilizing wikis and blogs that draw on the librarians' technical acumen. Several faculty members dedicate the second class meeting of the course to a librarian-led class discussion addressing student assumptions or biases regarding the research process. One faculty/librarian partnership collaborates closely with the United States Holocaust Memorial Museum, visiting that library and museum together with the students.

\section{Formative Assessment}

Assessments are categorized as either formative, providing feedback during a process, or summative, giving final feedback at the conclusion of a process. Librarians from EIG deem the annual faculty survey as formative assessment. Faculty feedback informs librarian practice, provides discussion points for workshops of librarians and faculty, and generates dialogue between individual librarian and faculty partners.

EIG librarians meet to discuss practice and pedagogy regularly, so there is a ready forum for discussion of faculty comments and concerns. Following the first report, members focused primarily on the faculty articulation of the recursive nature of writing and research. Did this theoretical frame inform our practice? Where would this theoretical stance best evidence itself? Subsequent reports have prompted similar discussions within EIG.

During the course of a semester, it is challenging to schedule gatherings of librarians and faculty for discussion. Nevertheless, following the first survey report, faculty and librarians met for a joint forum in response to the initial survey findings. Participating faculty mem- bers and librarians presented examples of exercises used in past classes that could clarify the research/writing relationship for students. Instructor Pam Presser, for example, discussed her annotated bibliography assignment: she requires students to include sources they considered but ultimately discarded. The annotation for those sources should document how their argument and thesis has changed as their writing progresses.

Following the second survey report, faculty and librarians again met for a discussion regarding survey findings. This included how to guide students to the "best" source instead of an "easy" source to support their research question. This forum explored the differences between student, faculty, and librarian approaches to source selection. Instructor Michael Svoboda introduced his process for tapping into disciplinary discourse as a supplement or portal to library sources. Through immersion into online communities focused on a subject, students encountered leads to authoritative information that his partner librarian, Sarah Palacios-Wilhelm, then integrated into her instruction.

The annual report of faculty feedback is a springboard for discussion between faculty and librarian partners regarding course specifics and application of new insights into assignments. The literature emphasizes communication as essential to collaboration. EIG task force members constructed the first faculty survey as an assessment tool but also value it as a communication strategy. Each year, the resulting discussions have extended understanding between library and faculty partners and enhanced opportunities for collaboration. Ultimately, students benefit as their writing courses blend perspectives and skills from a collaborative team. 


\section{Addendum 1: Fall 2005 Faculty Assessment}

1. What were your learning goals of the Library Instruction session(s):

2. How effectively did the library sessions: Please rank the following on a scale of 1 (poor) to 5 (excellent).

Meet the information needs of your students: $\begin{array}{lllll}1 & 2 & 3 & 4 & 5\end{array}$

Meet your expectations:

Support the content of course:

12

Comments (optional)

3. Did students ask research-related questions following the library sessions? What kinds of questions did they ask?

4. Did you discuss library materials with your students before the library session?

- Introduce electronic resources (i.e., article databases, electronic journals, Web sites) that pertain to the subject matter?

Introduce print materials (i.e., reference books, subject-specific books, journals, archival materials) that pertain to the subject matter?

$\square$ Other (please explain)

5 . How would you rate the average quality of student research conducted for this class? Please rank the following on a scale of 1 (poor) to 5 (excellent).

$\begin{array}{lllllll}\text { Selected appropriate materials: } & 1 & 2 & 3 & 4 & 5\end{array}$

$\begin{array}{llllll}\text { Utilize both print and electronic materials: } & 1 & 2 & 3 & 4 & 5\end{array}$

$\begin{array}{lllllll}\text { Thoroughness of research in papers: } & 1 & 2 & 3 & 4 & 5\end{array}$

Comments (optional):

6. What level of knowledge should a student demonstrate about the use of the library for research after the library session? Please check the appropriate level for each resource.

Using article databases to find articles:

$\square$ don't know $\square$ an awareness of $\quad \square$ competent $\square$ not applicable

Able to differentiate between scholarly and popular sources:

$\square$ don't know $\square$ an awareness of $\square$ competent $\square$ not applicable

Using reference materials for background information:

$\square$ don't know $\square$ an awareness of $\quad \square$ competent $\quad \square$ not applicable

Using the library catalog to locate books:

$\square$ don't know $\square$ an awareness of $\square$ competent $\square$ not applicable

Comments (optional) 
7. Did the research sessions enhance this course? Please use the following scale of 1 (poor) to 5 (excellent).

Tailored instruction to course assignments: 1

2

3

4

5

Comments (optional)

The library sessions were scheduled at appropriate junctures:

$\begin{array}{llll}1 & 2 & 3 & 4\end{array}$

5

Comments (optional)

8. Did you learn anything new during the library sessions that will help you with your research and/or teaching?

\section{Addendum 2: Research Curriculum for UW20}

It is the library's recommendation that each UW 20 section include two library instruction sessions. Instruction librarians are available throughout the semester; however, students will benefit most from sessions scheduled at the time in which they will begin research for a specific assignment.

The research curriculum has been designed to incorporate information literacydefined as the ability to locate, evaluate, and use information effectively - with the goals of the writing program. To provide all UW20 students with a solid foundation in library research, all students will be introduced to the research skills addressed under "Effective search techniques in the online catalog and databases." The other topics covered can be tailored toward the unique research needs of your students based on the nature of the writing assignment.

\section{Translating a Topic to an Information Need}

Using a topic or research question, identify what kind of information is needed and where to locate that information. Refine a research topic by narrowing a broad search statement or broadening a narrow search statement.

Expected outcome: Students will learn how to identify what kind of information is needed (books, articles, etc.) and how to refine a topic to a more manageable focus by modifying the scope or direction of a research question.

\section{Search terms}

Examine the difference and apply keyword, subject, and free text searching and apply within the WRLC Libraries Catalog and select databases. Assist in developing keywords and creating search statements to use when searching for information.

Expected outcome: Students will demonstrate an understanding of keyword, subject heading, and free-text search and use effectively and appropriately and to search their topic by creating appropriate search statements 


\section{Database Language (Boolean Operators and Truncation)}

Create search statements using Boolean logic and refine search terms using appropriate truncation symbols.

Expected outcome: Students will demonstrate an understanding of the concept of Boolean logic and construct search statements using Boolean operators.

\section{Search for books using the WRLC Libraries Catalog}

Search for books using the following fields in the WRLC Libraries Catalog: title, author, subject heading, and guided keyword.

Expected outcome: Students will demonstrate the ability to search for books using the title, author, subject heading, and guided keyword search features.

\section{Search for articles using online databases}

Search for articles using a multidisciplinary database and a subject-specific database relevant to theme of the course.

Expected outcome: Students will be able to recognize when to use a general or subject-specific database to locate articles and demonstrate the ability to locate articles using online databases.

\section{Notes}

1. Sustaining Momentum, Maximizing Strength (Washington, D.C.: George Washington University, 2003), 7. Also available online at www.gwu.edu/\%7Eacademic/OfficeVicePresident/pdf/ Strg_GWBook.pdf. [Accessed 4 February 2009].

2. Ada Ducas and Nicole Michaud-Oystryk, "Toward a New Enterprise: Capitalizing on the Faculty/Librarian Partnership," College and Research Libraries 64 (Jan. 2003): 55-74.

3. Annmarie B. Singh, "A Report on Faculty Perceptions of Students' Information Literacy Competencies in Journalism and Mass Communication Programs: The ACEJMC Survey," College and Research Libraries 66 (July 2005): 294-310.

4. Dick Raspa and Dane Ward, The Collaborative Imperative: Librarians and Faculty Working Together in the Information Universe (Chicago: Association of College and Research Libraries), 2000.

5. Trudi E. Jacobson and Thomas P. Mackey, Information Literacy Collaborations That Work (New York: Neal-Schuman Publishers), 2007.

6. Rachel Callison, Dan Budny, and Kate Thomes, "Library Research Project for First-Year Engineering Students: Results from Collaboration by Teaching and Library Faculty," Reference Librarian 43, no. 89 (2005): 93-106.

7. Ann M. Fiegen, Bennet Cherry, and Kathleen Watson, "Reflections on Collaboration: Learning Outcomes and Information Literacy Assessment in the Business Curriculum," Reference Services Review 30, no. 4 (2002): 307-18.

8. Linn Lampert, "'Getting Psyched' about Information Literacy: A Successful Faculty-Librarian Collaboration for Educational Psychology and Counseling," Reference Librarian 43, no. 89 (2005): $5-23$.

9. L. Sanborn, "Improving Library Instruction: Faculty Collaboration," Journal of Academic Librarianship 31, no. 5 (2005): 477-81.

10. Kate Manuel, Susan E. Beck, and Molly Molloy, "An Ethnographic Study of Attitudes Influencing Faculty Collaboration in Library Instruction," The Reference Librarian 89/90 (2005): 139-61.

11. Lisa M.Givens and Heidi Julien, "Finding Common Ground: An Analysis of Librarians' Expressed Attitudes Towards Faculty," The Reference Librarian 89/90 (2005): 25-38.

12. Kathy Charmez, "Grounded Theory: Objectivist and Constructivist Methods," in Handbook of Qualitative Research, eds. Norman K. Denzin and Yvonna S. Lincoln (Thousand Oaks, Calif.: Sage Publications), 2000.

13. Carol Hayes, et al., Big Read (faculty working paper, George Washington University), 2007. 


\section{“An investment in knowledge pays the best interest." \\ - Benjamin Franklin}

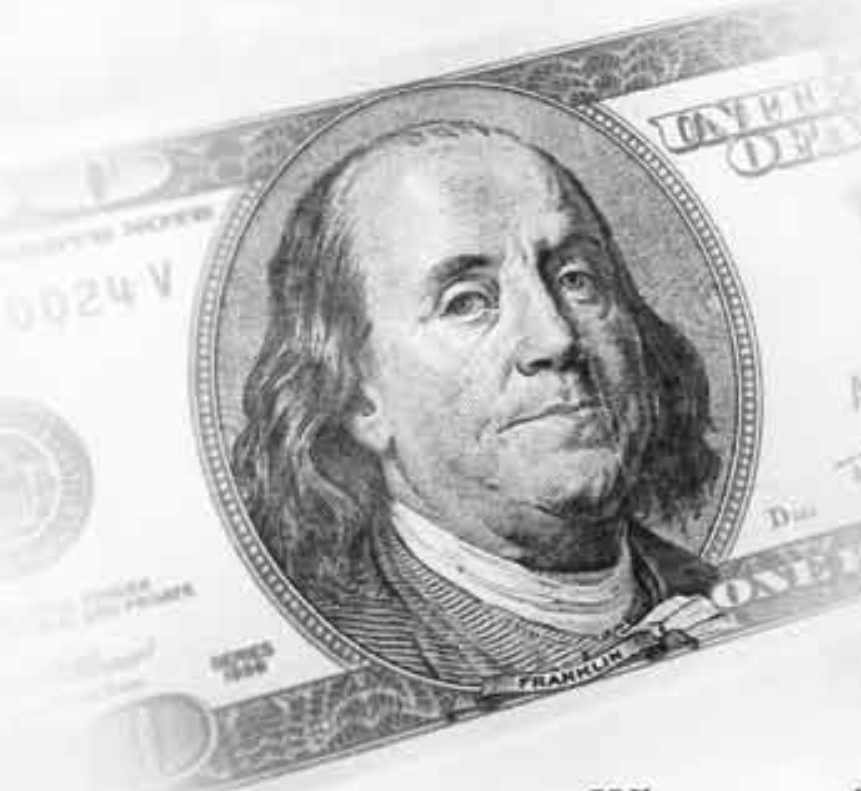

When every dollar counts, get the most out of your budget with Choice Reviews Online.

The perfect companion to a CHOICE print subscription:

- Access to over 145.000 CHOICE reviews - Downlead, print or e-mail search results - Ability tei create a customized profile

- Create, save and e-mail lists

- Search all CHOICE content

- View exclusive online matcrial

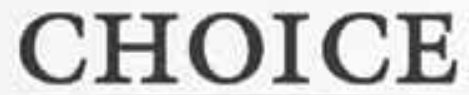

R E V I E W S O N L I N E

To learn more about Choice Reviews Online. visit us at the Charleston Conference Vendor Showcase. November 4, 2009.
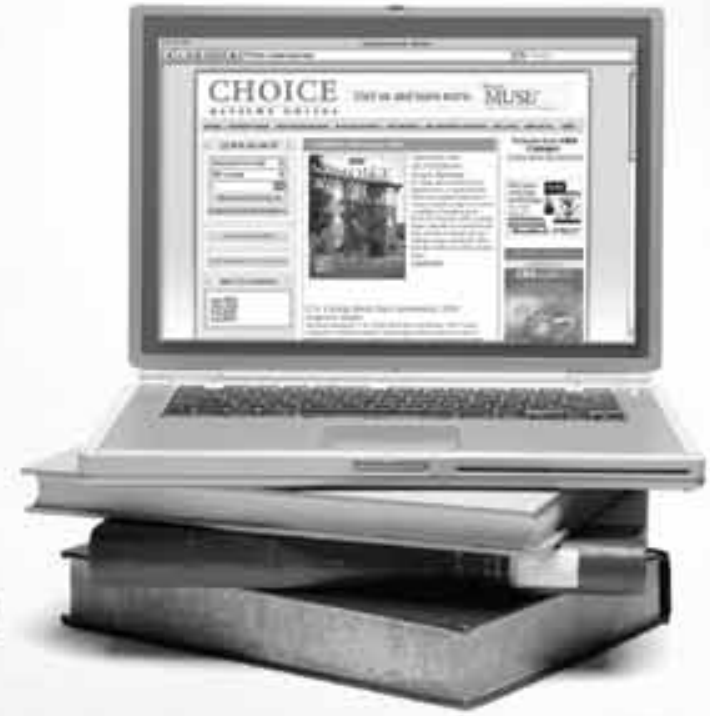